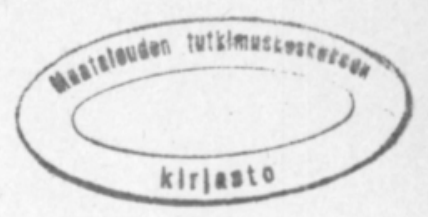

\title{
Nutritive value of full-fat rapeseeds for growing pigs
}

\author{
Maija-Liisa Salo \\ Department of Animal Husbandry, University of Helsinki, 00710 Helsinki 71
}

\begin{abstract}
The digestibility and nutritive value of full-fat, ground rapeseeds of two low-erucic acid, low-glucosinolate varieties, Candle (Brassica campestris) and Regent (B. napus), were determined for three pigs, weighing about $40 \mathrm{~kg}$ each. The ME values were 18.72 and $20.26 \mathrm{MJ} \mathrm{ME} / \mathrm{kg} \mathrm{DM}$, the $\mathrm{NE}$ values 1.58 and $1.70 \mathrm{FU} / \mathrm{kg}$ DM (FU = $0.7 \mathrm{~kg}$ starch) and the DCP values 155 and $201 \mathrm{~g} \mathrm{DCP} / \mathrm{kg}$ DM, respectively, for the two varieties. Nitrogen balances in the same trials were 21.0 and $22.0 \mathrm{~g} \mathrm{~N} / \mathrm{d}$.

Twenty-eight freshly weaned piglets averaging $11 \mathrm{~kg}$ in weight were fed during four weeks 1) a control diet containing barley and skim milk powder, or 2) the control diet with $10 \%$ finely ground Candle seeds incorporated. The calculated energy and DCP values of the diets were alike. The growth rates of both groups were equal, as were the palatabilities of the diets. The feed conversion figures were 2.0 and $2.1 \mathrm{FU} / \mathrm{kg}$ liveweight gain, respectively. Accordingly, the energy value of Candle seeds was a little poorer for piglets than for the older growing pigs.
\end{abstract}

\section{Introduction}

Rapeseeds are usually cultivated for the food oil industry and only the defatted meal is used for animals. The whole seeds can also be fed to animals, of course. Low-erucic acid, low-glucosinolate rapeseeds have been successfully included at $10 \%$ level in the diets of laying hens, from 10 to $20 \%$ in the diets of broiler chickens (LEESON et al. 1978) and up to $21.5 \%$ in the diets of turkeys (Moody et al. 1978). High-glucosinolate seeds, however, have decreased the production of poultry at the $10-20 \%$ inclusion level (Woody et al. 1972, Olomy et al. 1975 a, 1975 b). Low-glucosinolate seeds have proved to be a useful protein and energy source also in lamb milk replacers (SEOANE et al. 1976), and have been found to improve the milk production of dairy cows (ANON. 1978).

In the present study the full-fat ground rapeseeds of to low-erucic acid, low-glucosinolate varieties, Candle (Brassica campestris) and Regent (B.napus), were investigated as feeds for pigs. In the first trial the digestibility and nutritive value of the seeds was determined for growing pigs. In the second trial freshly weaned piglets were fed diet containing $10 \%$ Candle rapeseeds. 


\section{Digestibility and feed value of seeds}

\section{Materials and methods}

The diets contained $20 \%$ of milled rapeseeds, barley as a basic component, and skim milk powder sufficient to bring the crude protein content to $120 \mathrm{~g}$ $\mathrm{DCP} / \mathrm{FU}$. Minerals and vitamins were incorporated in the diets at standard levels. The composition of the rapeseeds is set out in Table 1.

Table 1. Composition of rapeseeds, $\%$ of dry matter.

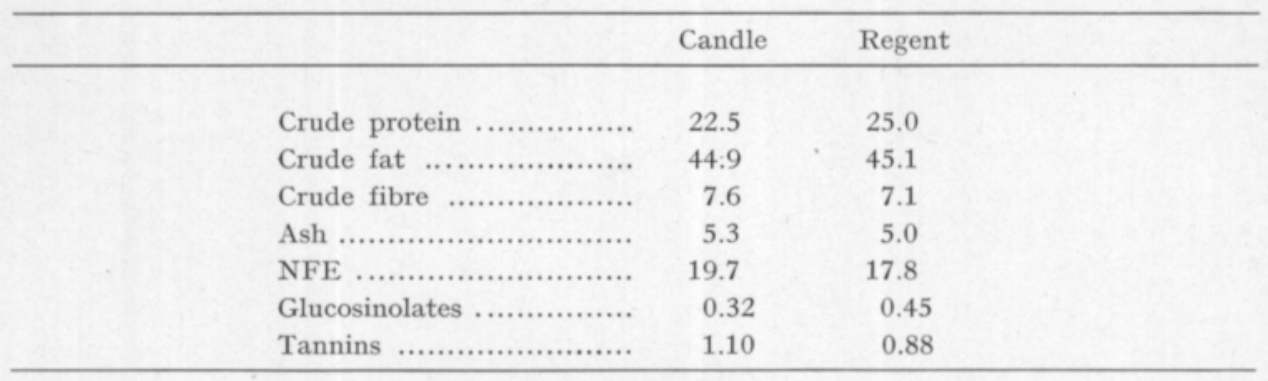

The digestibility trials were performed with three castrated pigs weighing about $40 \mathrm{~kg}$. The pigs were kept in digestibility cages in a room maintained at $13-18^{\circ} \mathrm{C}$. A vermicide was given to the animals at the beginning of the trial.

The daily ration of $1.6 \mathrm{FU}$ was given as two meals. Barley, rapeseeds skim milk powder, and mineral and vitamin mixtures were weighed separetely, and given mixed with two volumes of water. The pigs ate the ration immediately and were then offered water.

The preliminary period was $\mathbf{1 5}$ days, and the collection period $\mathbf{5}$ days. The faeces and urine were collected in the morning and samples of fixed amount were taken for analysis. Sulphuric acid was added to the urine collection pail to keep the acidity under $\mathrm{pH}$ 3. At the end of period spatterings of feed were collected from a plastic sheet placed in front of the trough, and subtracted from the total amount of feed given.

The dry matter determinations were made at $103^{\circ} \mathrm{C}$, and the samples for analysis dried in vacuum at $50^{\circ} \mathrm{C}$. Feeds and faeces were milled with a sieve of $0.5 \mathrm{~mm}$.

The feed analyses were performed according to standard procedures. The determinations of glucosinolates and tannins were made at the State Institute of Agricultural Chemistry.

The digestibility of the barley meal was determined in a separate trial and the digestibility coefficients for skim milk powder were taken from Feed Tables (Eriksson et al. 1972). The digestibility of rapeseeds was then calculated by subtraction.

The metabolizable energy and net energy values were calculated using factors and models of NJF's Feed Tables (Anon. 1969). 
Results and discussion

The digestibility coefficients and calculated energy and DCP values are presented in Tables 2 and 3.

Table 2. Digestibility coefficients of rapeseeds.

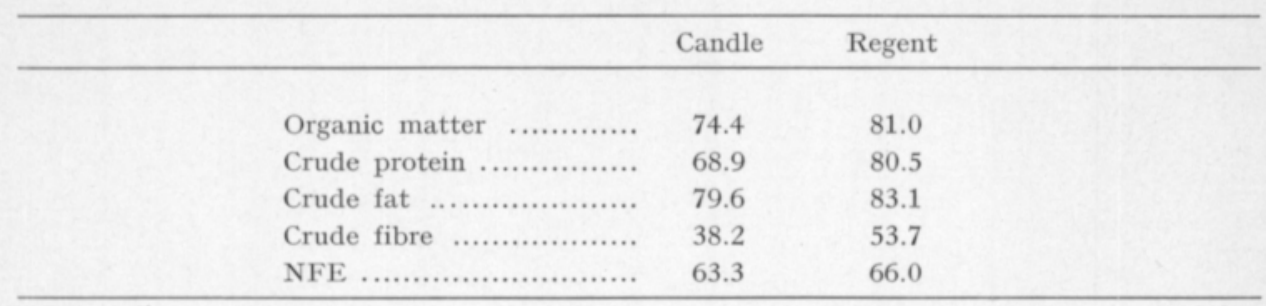

Table 3. Nutritive value of rapeseeds.

\begin{tabular}{|c|c|c|}
\hline & Candle & Regent \\
\hline Metabolizable energy, $\mathrm{MJ} / \mathrm{kg}$ DM & 18.72 & 20.26 \\
\hline 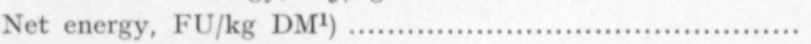 & 1.58 & 1.70 \\
\hline 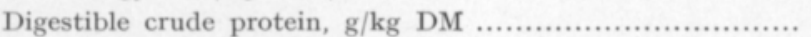 & 155 & 201 \\
\hline
\end{tabular}

1) $\mathrm{FU}=0.7 \mathrm{~kg}$ starch.

Information about nutritive value of full-fat rapeseeds for pigs is scant. The only figure found was the ME value of $21.1 \mathrm{MJ} / \mathrm{kg}$ DM in the Feed Tables of the DDR (NEHRING et al. 1970), which is slightly higher than the value here for the Regent seeds. The difference may be due to the fact that the present seeds were ground fairly coarsely, some whole seeds being visible in the meal. (A separate trial revealed that the pig is unable to digest unmilled rapeseeds.) However, high variation in rape varieties or seed batches seems to occur. For instance, the Swedish Feed Tables give a ME value of $5.11 \mathrm{Mcal} / \mathrm{kg}$ DM for ruminants (Eriksson et al. 1972), and the Norwegian Tables 4.41 Mcal/kg DM (BREIREM \& Номв 1970).

In the present study the Regent seeds ( $R$. napus) were found to be a little better in nutritive value than the Candle seeds (B. campestris) (Tables 2 and 3). SibBald and PRICE (1977) have reported an even larger average difference between B. napus and B. campestris seeds (5.08/4.52 Mcal ME/kg DM for poultry). The Candle variety, however, has a thinner seed coat than the older varieties and thus a better energy value. Mutztar et al. (1978) have found its AME value to be similar to that of Tower for poultry (4.4/4.5 Mcal, respectively).

The nitrogen balances for Candle and Regent seeds were alike, 21.0 and $22.0 \mathrm{~g} \mathrm{~N} / \mathrm{d}$, respectively. The protein of the seeds constituted only about $25 \%$ of the protein content of the rations, however.

The FU value of full-fat rapeseeds for growing pigs proved to be about one and a half times, and the DCP value $/ \mathrm{kg}$ DM almost two times the value 
of barley. An additional advantage of the rape seeds compared with barley is the better amino acid composition and higher linolic acid content (see Nehring et. al 1970.) From the cost point of view, however, barley is a better feedstuff than the rapeseeds.

\section{Rapeseeds as feed for freshly weaned pigs}

\section{Materials and methods}

To obtain further information on the value of rapeseeds, a four-week growth trial was conducted with 28 freshly weaned pigs. The piglets were chosen because with older pigs the high oil content of the diet is reflected in lowered quality of the carcass.

The age of the pigs at the beginning of the trial was from 4.5 to 6 weeks and the average weight $11.1 \mathrm{~kg}$. The pigs were given a vermicide and divided according to weight, age and sex into two equal groups, each of which was further divided and placed into two pens according to weight. The weight gain of pigs was followed individually and their feed consumption per pen.

The ration of the control group consisted of barley, skim milk powder, minerals and vitamins. The experimental diet differed from the control ration only in a $10 \%$ rapeseed content; proportions of barley and skim milk powder were reduced so that the crude protein contents of the diets equal (Table 4). The rapeseeds were ground together with barley using a $2 \mathrm{~mm}$ sieve. The milling was successful and no whole seeds were detected in the meal.

The feeds were given as two meals daily, mixed with warm water. Between meals the dry meal was put in the troughs.

Table 4. Composition and nutritive value of the diets of the piglets.

\begin{tabular}{|c|c|c|}
\hline & Experimental group & Control group \\
\hline Dry matter, $\%$.............. & 91.0 & 91.0 \\
\hline$\%$ of dry matter & & \\
\hline 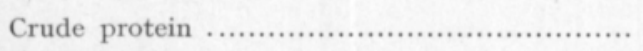 & 22.0 & 21.9 \\
\hline 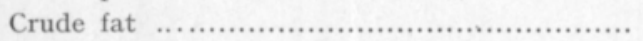 & 5.7 & 1.4 \\
\hline 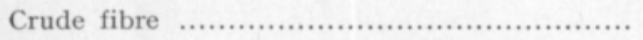 & 4.0 & 3.4 \\
\hline 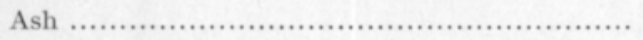 & 5.9 & 6.2 \\
\hline 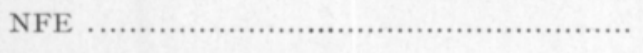 & 62.4 & 67.1 \\
\hline NE value, FU/kg DM ..... & $\left.1.19^{1}\right)$ & 1.15 \\
\hline DCP value, g/kg DM ............................... & $195 \quad 1)$ & 200 \\
\hline
\end{tabular}

1) Calculated using rapeseeds feed values as presented in Table 3 .

\section{Results and discussion}

The pigs were weighed twice at the beginning and end of the trial and twice during the trial. The growth rates of the two groups were very alike, the average daily gain being $485 \mathrm{~g}$ for experimental group and $487 \mathrm{~g}$ for control 
group (Fig. 1). The palatability of the experimental feed was better than the control feed in the dry form, but when mixed with water no difference was found. No sickness was recorded during the trial.

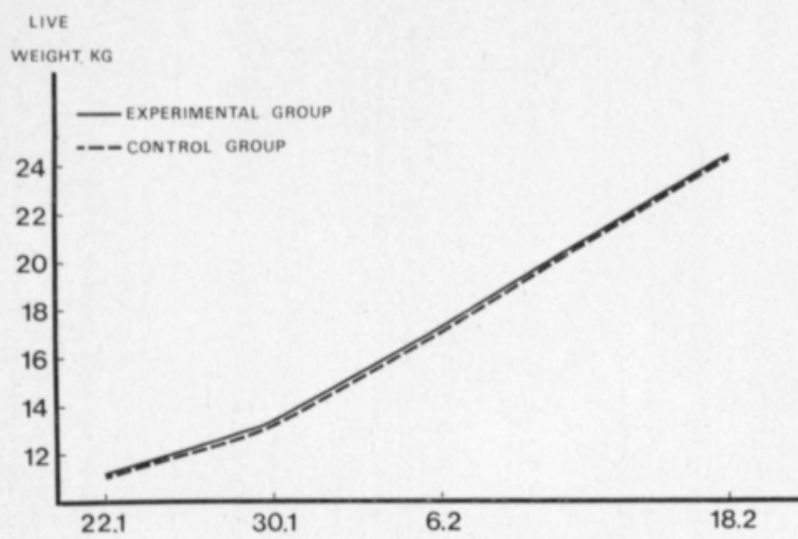

Fig. 1. Growth rates of the piglets.

The consumption of feed was also almost equal. The average daily intakes were $921 \mathrm{~g}$ and $902 \mathrm{~g}$ for the experimental and control groups, respectively. The utilization of feed was a little better in the control group: an average of $2.0 \mathrm{FU} / \mathrm{kg}$ liveweight gain against $2.1 \mathrm{FU} / \mathrm{kg}$ in the experimental group. The energy value of the experimental diet thus proved to be a little lower than the value calculated for the $40-\mathrm{kg}$ pigs (Table 4 ). The $10-25 \mathrm{~kg}$ piglets thus utilized the rapeseeds somewhat less efficiently, despite the fact that the rapeseeds fed to piglets were ground much more finely than those used in the digestibility trial.

\section{REFERENCES}

Anon. 1969. Nordisk Jordbrugsforskning. Fodermiddeltabel. 40 p. Gjøvik.

Anon. 1978. Mer fett till korna ökar avkastningen. Lantmannen 22/1978: 30.

Breirem, K. \& Номв, T. 1970. Fôrmidler og fôrkonservering. 459 p. Gjøvik.

Eriksson, S., Sanne, S. \& Thомкe, S. 1972. Fodermedlen. 299 p. Borås.

Leeson, S., Slinger, S. J. \& Summers, J. D. 1978. Utilization of whole Tower rapeseed by laying hens and broiler chickens. Can. J. Anim. Sci. 58: 55-61.

Moody, D. L., Slinger, S. J., Leeson, S. \& Summers, J. D. 1978. Utilization of dietary Tower rapeseed products by growing turkeys. Can. J. Anim. Sci. 58: 585-592.

Muztar, A. J., Likuski, H. J. \& Slinger, S. J. 1978. Metabolizable energy content of Tower and Candle rapeseeds and rapeseed meals determined in two laboratories. Can. J. Anim Sci. 58: 485-492.

Nehring, K., Beuer, M. \& Hoffmann, B. 1970. Futtermitteltabellenwerk. 460 p. Berlin.

Olomu, J. M., Robblee, A. R., Clandinin, D. R. \& Hardin, R. T. 1975 . Evaluation of fullfat Span rapeseed as an energy and protein source for laying hens. Can. J. Anim Sci. 55: $219-222$.

- , Robblee, A. R., Clandinin, D. R. \& Hardin, R. T. 1975 . Utilization of full-fat rapeseed and rapeseed meals in rations of broiler chicks. Can. J. Anim. Sci. 55: 461 466. 
Seoane, J. R., Gorrill, A. D. L., Crampton, L., Jones, J. D., Macintyre, T. M., Nicholson, J. W. \& Stevenson, R. G. 1976. Low-glucosinolate, low-erucic acid full-fat rapeseed (cv. Tower) as a protein and energy source in lamb milk replacers. Can. J. Anim. Sci. 56: $393-400$.

Sibbald, I. R., \& Price, K. 1977. The true metabolizable energy values of the seeds of Brassica campestris, B. birta and B. napus. Poult. Sci. 56: 1329-1331.

Woodly, A., Summers, J. D. \& Bilanski, W. K. 1972. Effects of heat treatment on the nutritive value of whole rapeseed for poultry. Can. J. Anim. Sci. 52: 189-194.

Ms received August 27, 1979.

\title{
SELOSTUS
}

\section{Rypsin- ja rapsinsiementen rehuarvo lihasioilla}

\author{
Maija-Lirsa Salo \\ Helsingin yliopiston kotieläintieteen laitos, 00710 Helsinki 71.
}

Niukasti erukahappoa ja glukosinolaatteja sisältävien jauhettujen Candle-rypsin (Brassica campestris) ja Regent-rapsin (B. napus) sulavuus ja rehuarvo määritettiin kolmella noin 40 $\mathrm{kg}$ painoisella lihasialla. Muuntokelpoisen energian arvoksi saatiin $18.72 \mathrm{ja} 20.26 \mathrm{MJ} / \mathrm{kg} \mathrm{ka}$, nettoenergia-arvoksi 1.58 ja $1.70 \mathrm{ry} / \mathrm{kg}$ ka sekä valkuaisarvoksi 155 ja $201 \mathrm{~g}$ srv/ka ka. Typpitaseet olivat 21.0 ja $22.0 \mathrm{~g} \mathrm{~N} / \mathrm{pv}$.

28 äsken vieroitettua, keskimäärin $11 \mathrm{~kg}$ painoista porsasta oli neljän viikon ajan ruokintakokeessa, jossa puolet porsaista sai ohrasta ja rehumaitojauheesta koostuvaa vertailuseosta, toinen puoli koeseosta, mikä sisälsi $10 \%$ hienoksi jauhettua Candle-rypsiä. Ohraa ja rehumaitojauhetta oli koeseoksesta vähennetty siten, että lasketut energia- ja valkuaisarvot olivat lähes samat. Ryhmien kasvu oli täysin samanlaista, koeryhmän porsaiden keskimäärin $485 \mathrm{~g}$, vertailuryhmän $487 / \mathrm{pv}$. Rehuseosten maittavuudessa ei ollut eroa. Rehun hyväksikäytto̊ oli koeryhmillä 2.1 ry ja vertailuryhmällä 2.0 ry/lisäkasvukilo. Tämän mukaan 10-25-kiloiset porsaat käyttivät rypsin siemeniä hyväkseen vähän huonommin kuin 40-kiloiset lihasiat. 